\title{
The essential role of farm capital in the sustainability of smallholder farms in West Java (Indonesia)
}

\author{
Pria Sembada ${ }^{1,2, *}$, Guillaume Duteurtre ${ }^{2,3}$ and Charles-Henri Moulin ${ }^{2}$ \\ ${ }^{1}$ Sekolah Vokasi, IPB University (Bogor Agricultural University), Jln. Kumbang No.14, Kampus IPB Cilibende, Bogor, Indonesia \\ ${ }^{2}$ UMR Systèmes d'élevage méditerranéens et tropicaux (SELMET), INRA-CIRAD-Montpellier SupAgro-Univ. Montpellier, 2 place \\ Pierre Viala, 34060 Montpellier Cedex 1, France \\ ${ }^{3}$ CIRAD, UMR SELMET, Campus International de Baillarguet, F-34398 Montpellier, France
}

\begin{abstract}
Smallholder farms represent the largest population of dairy cattle farms in Indonesia. Dairy activities can play an important role to secure the livelihood of smallholder farms. However, small farms face several constraints and challenges to be sustainable in the future. To assess the sustainability of smallholder dairy farms and to understand in what conditions farms are more sustainable, we conducted a study in two districts of the West Java Province. Our method was based on participatory meetings that allowed us to identify "critical features" of the local farming systems, and associated indicators. From discussions with local stakeholders, we proposed 6 "strategic indicators" of sustainability. Five of those indicators were related to the social and economic dimensions of sustainability, which appeared to be crucial in the local context. To assess the sustainability of farms based on those 6 indicators, we collected secondary data from the local cooperative, and carried out a formal field survey to 355 farmers from May to August 2015. Results showed that the most sustainable farms were those who had highest capital and diversified activity. Farms which had low capital but had additional activity were more sustainable than specialized ones. Whereas the level of farm income appears to be linked directly to farm capital, pluriactivity contributes to reduce risks related to dairy business and to gain benefit from synergies between activities. In the future, policies and projects to enhance farm capital and farmers' pluriactivity will be needed to support the sustainability of smallholder farms.
\end{abstract}

Keywords: assessment / dairy / Indonesia / smallholder farms / sustainability

Résumé - Le rôle essentiel du capital d'exploitation dans la durabilité des petites exploitations à Java Ouest (Indonésie). Les petites exploitations constituent la majorité des fermes laitières en Indonésie. Les activités laitières jouent un rôle important pour assurer leur subsistance. Cependant, ces exploitations font face à plusieurs contraintes et défis pour être durables à l'avenir. Pour évaluer et identifier les conditions de la durabilité des exploitations laitières, une étude a été menée dans deux districts de la province de Java Ouest. Notre méthode repose sur des entretiens participatifs qui nous ont permis d'identifier des «points critiques » des systèmes d'élevage locaux, et de proposer des indicateurs de durabilité associés. À partir de réunions avec les acteurs locaux, nous avons identifié 6 indicateurs stratégiques. Parmi ces 6 indicateurs, 5 relèvent des dimensions sociales et économiques de la durabilité qui sont essentielles dans le contexte local. Pour évaluer la durabilité des exploitations à l'aide de ces 6 indicateurs et comprendre les facteurs qui expliquent les différences dans ces indicateurs, nous avons conduit une enquête auprès de 355 agriculteurs de mai à août 2015. Ces données ont été complétées par des données secondaires fournis par la coopérative sur ces 355 élevages. Les résultats ont montré que les exploitations les plus durables étaient celles qui possédaient le capital le plus élevé et qui étaient pluriactives. Pour les fermes avec un faible capital, celles qui étaient diversifiées étaient plus durables que celles qui étaient spécialisées. Alors que le niveau de capital impacte directement le niveau de revenu, la pluriactivité contribue à réduire les risques liés aux activités laitières et permet de bénéficier des synergies entre les activités. Notre étude souligne l'importance des programmes de crédit en appui aux exploitations et des programmes d'appui à la diversification des ménages ruraux pour accroître la durabilité des petites exploitations.

Mots clés : durabilité / évaluation / Indonésie / lait / petites exploitations agricoles

*Corresponding author: sembadapria@gmail.com 


\section{Introduction}

After several decades of research on livestock sustainable development, many questions remain on the sustainability of dairy farms. If some authors insist on the need to improve the environmental impact of milk production systems that are more and more intensified, some other underline the socioeconomic dimension of smallholder farms that needs to be strengthened (Herrero et al., 2009). This context appeals for new methods and tools to conduct sustainability assessment, in particular in developing and emerging countries where milk production is rising.

The concept of sustainability in livestock agriculture has been already proposed and discussed in various contexts. Sustainable livestock farming systems can be broadly defined as systems "that are economically viable for farmers, environmentally friendly, and socially acceptable" (Lebacq et al., 2013). In that perspective, assessing the sustainability of a given system requires defining attributes and criteria of sustainability, and identifying indicators of those criteria (López-Ridaura et al., 2002). Of course, those criteria and indicators must take into account the particularities of each sub-sector, and, in our case, the specific situation of the dairy sector.

At the global scale, smallholder dairy farmers represent the majority of the milk production units: the average size of the dairy farms in the world is 3.1 cows. All those small farms depend on milk production to be profitable and to develop sustainable business to secure their livelihood. However, small farmers face many challenges to be sustainable such as lack of fincancial means, low milk price, limited milk yield due to feed shortage, animal health and reproduction constraints (Moran, 2009) and problems related to waste management (Devendra, 2001). Smallholder dairy farms are therefore characterized by a tension between their potential for social inclusion, and their techno-economic constraints. This tension is essential for the future of dairy farming in the developing world.

In Indonesia, smallholder farms play an essential role for the development of the dairy sector. In the literature, smallholder farms of less than 20 cows are said to be "traditional", and mostly a "side business". They represent the largest share $(93 \%)$ of the national dairy cattle herd. Badan Pusat Statistik (2013) reported that dairy farms represent 144000 households, raising two to three dairy cows on average. Some other studies reported that shortage of capital is one of the main challenges for those smallholder dairy farmers to be competitive (Sembada et al., 2016). However, there is very few evidence in the literature about the specific situation of Indonesian dairy smallholders with regards to their sustainability.

The objective of our paper is to identify the main factors affecting the sustainability of smallholder dairy farms in Indonesia, in order to propose some policy recommendations for promoting sustainable dairy development.

\section{Methods}

\subsection{Study site}

We conducted a study in the West Java Province. This province is essential for milk production in Indonesia. The Province has a rich and fertile volcanic soil and is concerned with very high urbanization. Its population density is $1500 \mathrm{hab} . / \mathrm{km}^{2}$. We selected 2 districts from West Java Province: Bandung Barat and Subang because of the presence of an important milk cooperative: the North Bandung Milk Producers Cooperative (Koperasi Peternak Sapi Bandung Utara-KPSBU). KPSBU represents more than 7000 smallholder milk producers, among which around 4000 were considered as "active members", i.e. involved in milk deliveries during the last year before the survey.

\subsection{Research design}

We carried out a field study from May 2015 to May 2016. Our strategy was to build different "profiles" of sustainability from a survey conducted on a large sample, and to identify the main factors explaining the differences between those profiles.

We adapted the MESMIS framework (López-Ridaura et al., 2002) to develop the indicators of sustainability that were pertinent in the local context. The research team started the evaluation process by conducting some preliminary visits and a literature review to understand the livestock farming system and its environment. The second step of the research was to conduct in-depth interviews with farmers and stakeholders involved in the management of local farming systems. The aim of the participatory analysis was to identify some "critical features". The choice of a set of criteria and indicators to assess the sustainability was discussed in several interviews with farmers and stakeholders. Those interviews identified the different critical points, criteria and strategic indicators. The 6 selected "strategic indicators" reflected economic, social, and environmental and dimensions of farms' sustainability. They were:

- owned land per family worker (Economic dimensionEc1);

- herd size per family worker (Economic dimension-Ec2);

- number of farm and non-farm activities (Economic dimension $-E c 3)$;

- total income per family worker (Social and Economic dimensions - SocEc l);

- farmers' willingness to continue dairy farming activity (Social dimension-Soc1);

- share of recycled waste on farm (Environmental dimension $-E n 1)$.

It is interesting to note that among the 6 indicators, 5 of them refer to the economic and social dimensions, which underlines the fact that stakeholder interviews and preliminary discussions have stressed the importance of those dimensions for farmers livelihoods and local communities.

We then conducted a formal survey to collect data on the 6 selected indicators, and on other factors influencing those indicators.

\subsection{Sampling and information taken into account}

Our surveyed covered a total of 355 farms and randomly chosen among all milk collecting point of the two districts. This sample represented $8.9 \%$ of the 4000 "active" members of KPSBU.

The information taken into account was divided into three categories adapted from Sembada et al. (2016): (i) farm 
structure and socio-demographic characteristics; (ii) dairy farming and feeding practices; (iii) technico-economic performances.

\subsection{Data analysis}

First, we calculated scores of sustainability for each of the six indicators and conducted a farms typology based on those active variables, in order to reveal different patterns of sustainability. In this step, we performed multivariate analysis (PCA and cluster analysis) that allowed us to propose 5 different "patterns" (Fig. 1).

For each of the 6 sustainability indicators, scores were given from 0 to 100 :

- to score "Ec1" and "Ec2", we considered a classification into 4 classes (quartiles), reflecting a continuous data distribution between minimum and maximum values:

$\mathrm{Xn} \leq \mathrm{Q} 1$ (low score $=0$ ),

$\mathrm{Q} 1<\mathrm{Xn} \leq \mathrm{Q} 3$ (medium score $=50$ ),

$\mathrm{Xn}>\mathrm{Q} 3$ (high score $=100$ );

- to score "Ec3", we identified three main activities: dairy business, crop farming and off-farm employment and the contribution of those three activities to the total income. We then calculated a "composite indicator of pluriactivity" reflecting the share of those 3 activities in the income. A farmer relying on dairying for $100 \%$ of his income would get a " 0 " value for this composite indicator. And a farmer relying on dairying, crop production and non-farm activity for $1 / 3$ of his income each, would get a value of " 100 " for this composite indicator. For this purpose, we used the above formula:

Composite indicator of pluriactivity $=100-\left(\sum_{1}^{3}\right.$ $\left.\left(x i-\frac{100}{3}\right)^{2}\right)$.

With $x_{i}$ (in \%)= contribution of the activity " $i$ " to the total income.

Based on this composite indicator, we calculated three contrasted scores of sustainability $(0,50,100)$ characterizing the low, medium and high values of this indicator;

- to score "SocEc1", we considered 5 classes of income. The building of those 5 classes was based on the poverty line (22.4 US\$/month) and the regional minimum wage for Subang Regency and Bandung Barat Regency (149 US $\$ /$ month). The maximum score (100) was given for the class with the highest income value;

- to score "Soc1", we considered 3 modalities of the answers:

(i) "no" (low score =0); (ii) "it's up to my children" (medium score $=50$ ); (iii) "yes" (high score $=100$ );

- to score the "En1", we estimated the share of livestock wastes that was recycled on farm from direct observation. If farmers did not evacuate waste into the river or surrounding area, they got the highest score (100). This score meant that they used manure in a biogas tank, as fertiliser or for sales. If they evacuated only part of the waste, they got the medium score (50). If the evacuated all wastes to the river, they got the lowest score $(0)$.

Second, we performed comparative and statistic analysis of the 5 patterns of sustainability. In this step, we performed
ANOVA, Tukey's test $(a l p h a=0.05)$ for some variables in order to identify significant factors.

\section{Results}

\subsection{Sustainability patterns}

We identified five patterns of sustainability based on our classification of the variables. We then used the PCA multivariate analysis to report the farms on 2 axes. The first component reflected Ec1, Ec2, and SocEc2 (Fig. 1). The second component reflected Ec3, and Soc1. En1 was not showed to be important in the classification.

Farmers of the first pattern (P1) were very small-size and diversified dairy farmers. They had a low score for Ec1 and Ec2. Each family raised only 2.3 cows on average and managed 0.1 ha owned land per farm. As a consequence, those farms had low score for income, despite the fact that they were involved in other economic activities to cover their needs, such as trade, wage work, and tourism. Their score in terms of pluriactivity was the highest (62.6 on average) with dairy income contributing to only $58.9 \%$ of their total income, which was 2650 US\$/year on average. Overall, those very small farms had low and medium scores of sustainability (Tab. 1 and Fig. 2).

Farmers of the second pattern (P2) were small and specialized dairy farmers. Their scores were low for almost all indicators of sustanaibility except for Soc1 (Tab. 2). Unlike farmers of P1, farmers of P2 did not rely on other activities to complement their income. Their score for pluriactivity was one of the lowest. But interestingly, they would see their children continuing their dairy business in the future. This can be explained by the fact that those farmers were the poorest families in our sample, having very few other opportunities for the future.

Farmers of the third pattern (P3) were also very small and specialized dairy farmers. The main difference with $\mathrm{P} 2$ was that they did not want their children to continue dairy business, with a score of 25 . As result, those farms were the less sustainable in our sample (Fig. 2).

Farmers of pattern $4(\mathrm{P} 4)$ were specialized smallholder dairy farmers, of a higher size in comparison to the other farmers of the sample. Their scores for Ec2 and Ec3 were the highest. They had on average 7 cows and generated 4370 US\$ per year. And their score for Ec1 was among the highest. Their score in pluriactivity was the lowest, indicating a high level of specialisation in dairy production. Their scores for En1 and Soc1 were medium. As a whole, their sustainability scores were medium (Tab. 2).

Farmers of the fifth pattern (P5) were smallholder dairy farmers of the same size as $\mathrm{P} 4$, but more diversified. They showed relatively high scores for Ec1 and Ec2. The score for Ec3 was among the 2 highest, and dairy activities accounted for only $64.8 \%$ of the total income. Those farms showed good scores for SocEc1 (with 3665 US\$ per year on average), Soc1, and En1. Most of them used the wastes as fertilizers or in a biogas system, and did not evacuate them into the local environment.

In comparison to all other patterns, farmers of pattern 5 had the most sustainable dairy farming systems: they had the more balanced profile for all indicators (Tab. 2 and Fig. 2). 

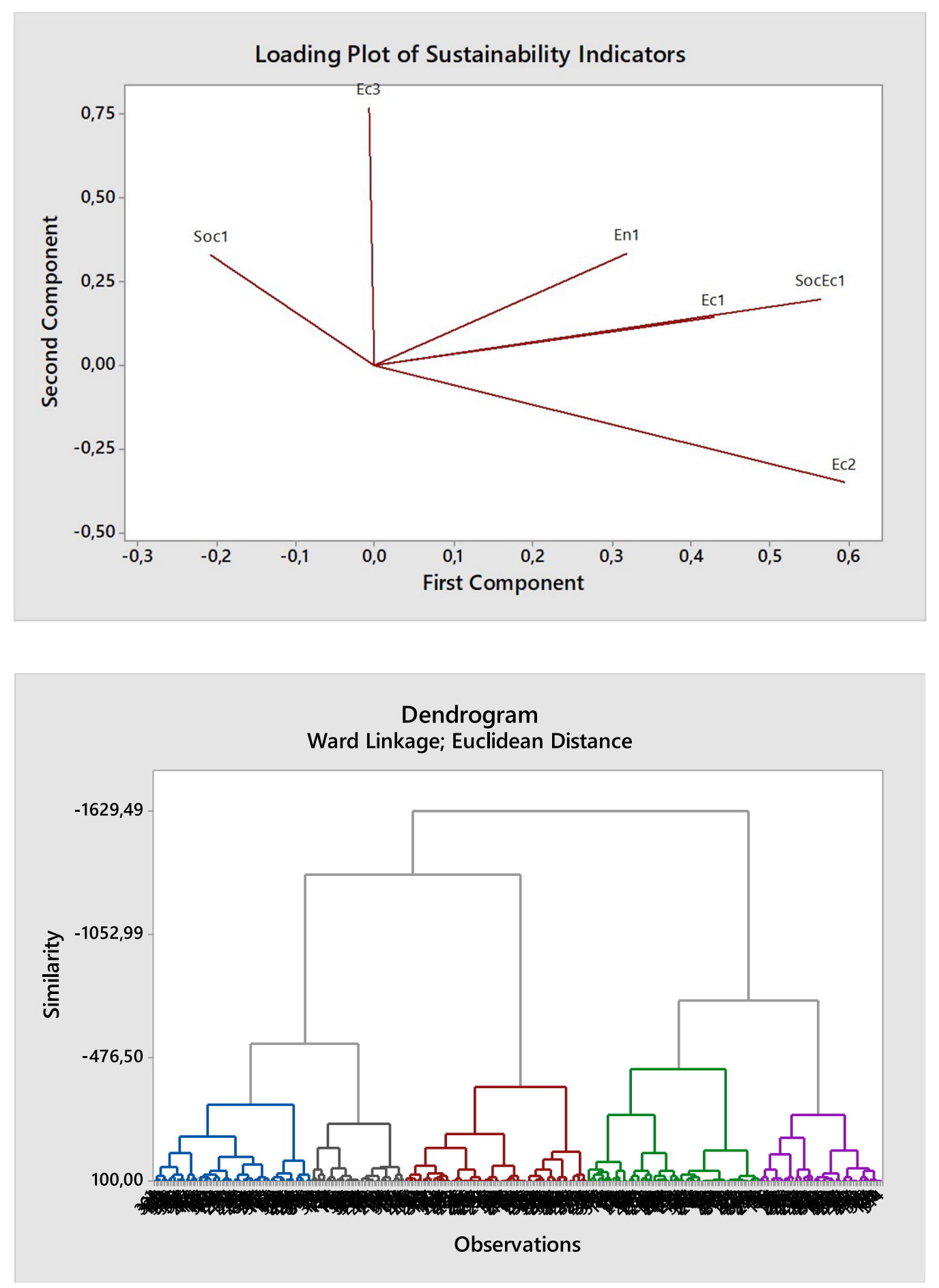

Fig. 1. Graphs and dendrogram of the PCA and cluster analysis.

Fig. 1. Graphiques et dendrogramme de l'ACP et classification ascendante hiérarchique.

\subsection{Characteristics of farms explaining their scores}

The statistical analyses presented in Table 3 give some indications on the relations between some factors and the scores of sustainability. Those results underline in particular the importance of the farm structure as well as of some specific farming practices.
Regarding structural factors, our study underlined the crucial role of farm capital. The 5 patterns were however strongly differentiated by capital endowment and by the level of pluriactivity. Since land ownership, herd size and pluriactivity had been chosen as "strategic indicators", (and since they were "active variables"), they played a significant role in the sustainability scoring. Our assessment clearly 
Table 1. Patterns of sustainability based on raw values of the strategic indicators (variables).

Tableau 1. Profils de durabilité basés sur les valeurs brutes des indicateurs stratégiques (variables).

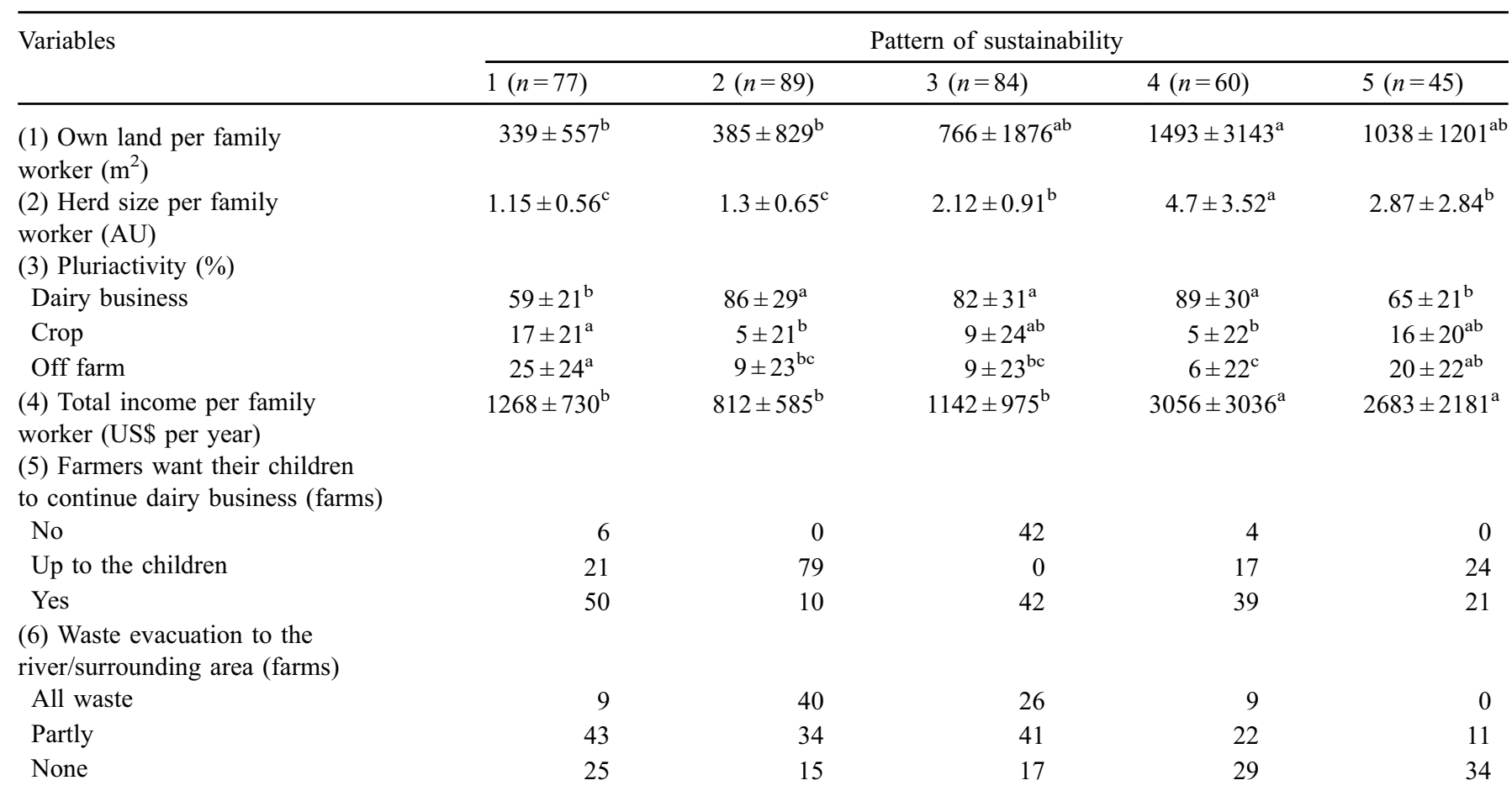

Means in the same column with a different superscript differ significantly $(P<0.05)$; NS not significant.

Source: Survey (2015).

differentiated farmers with low capital endowment (P1, P2 and P3) from those who had access to higher capital (P4 and P5). There was also a direct link between the number of dairy animals raised on farm and the level of dairy income. Farmers of P4 had 2 times more cows than farmers of P1, P2 and P3. Consequently, they sold more than twice more milk (1782 litres per months) and their income was also 2 times higher than the others'.

Our results also showed a clear difference between specialized dairy farms (P2, P3 and P4) and more diversified farms (P1 and P5). In those diversified farms, dairy remained the major activity, but it was conducted in complementarity with other crop and non-farm activities.

The analysis of the relations between dairy farming practices, technico-economic performances and sustainability scores underlines the importance of feed quantity and quality. Among the five patterns, there were no significant differences in milk productivity per cow, and in the amount of compound feed given to the cows, partly because of the high standard variations. This shows the high variability of technico-economic performances among farmers of the region. The only significant difference was observed in the amount of forage that was given to the cows. Farmers of P1 fed their cows with higher quantities of forage $(53 \mathrm{~kg}$ per cow per day), but with no impact on cow's productivity. This might indicate that those very poor farmers used forage of lower quality. Oppositely, farmers of P4 used a lower amount of fodders than the others $(34 \mathrm{~kg})$ with no impact on the productivity. This indicates that those specialized and intensified dairy farmers used forage of higher quality: they used more green forage and less paddy straw and crop residues than the others.

The high variability of practices and performances that are raised in the previous paragraph are also illustrated in the PCA score plot reported in Figure 1. This figure also shows that the first component of the PCA is composed of both herd size and waste management. This relates to the fact that the highest scores for waste management were reported for the larger farms (P4 and P5). This shows that waste management and intensification are not opposite, and that good environmental management practices can be promoted in all farms.

\section{Discussion}

\subsection{The role of farm capital endowment}

Our study suggests that in the Indonesian context, capital endowment has to be considered as the major component of farms' sustainability. Since rural families live on less than $0.5 \mathrm{ha}$, access to land and to dairy animals are two essential constraints that preclude the sustainable development of dairy farms. Farm capital directly affects forage autonomy and family income, which is very low for most of the surveyed farms. With an average income of 2885 US\$ per year and per farm all surveyed dairy farmers lived very close to the poverty line. The importance of capital endowment in the sustainability 

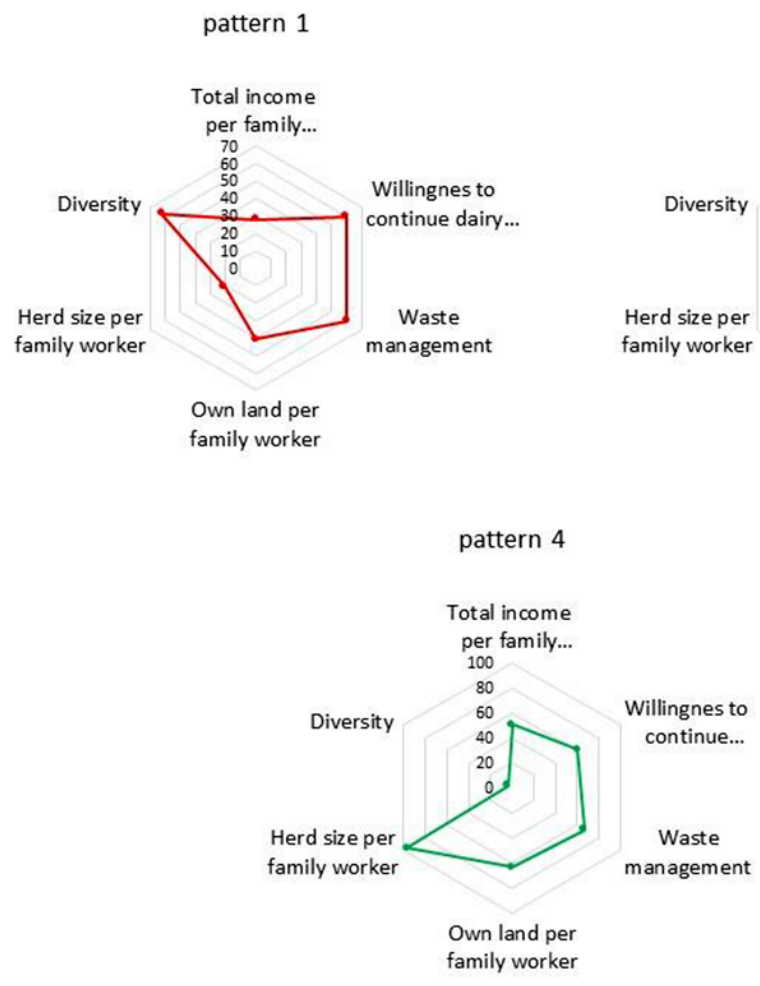

pattern 2

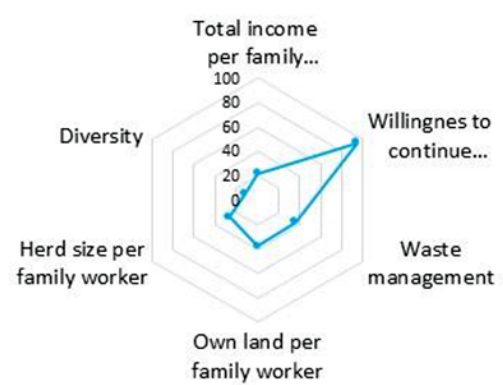

family worker

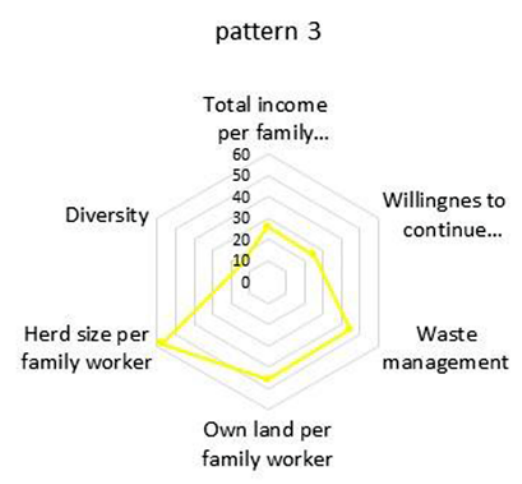

pattern 5

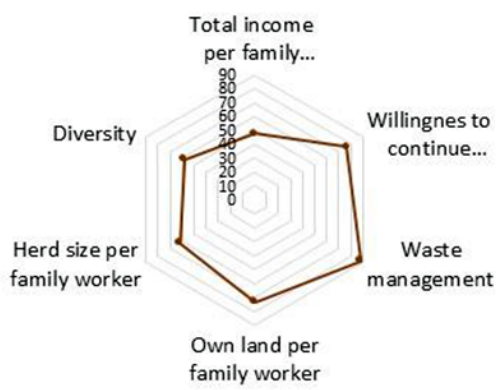

Fig. 2. Sustainability patterns.

Fig. 2. Modèles de durabilité.

Table 2. Patterns of sustainability based on scores (1-100).

Tableau 2. Profils de durabilité basés sur les scores (1-100).

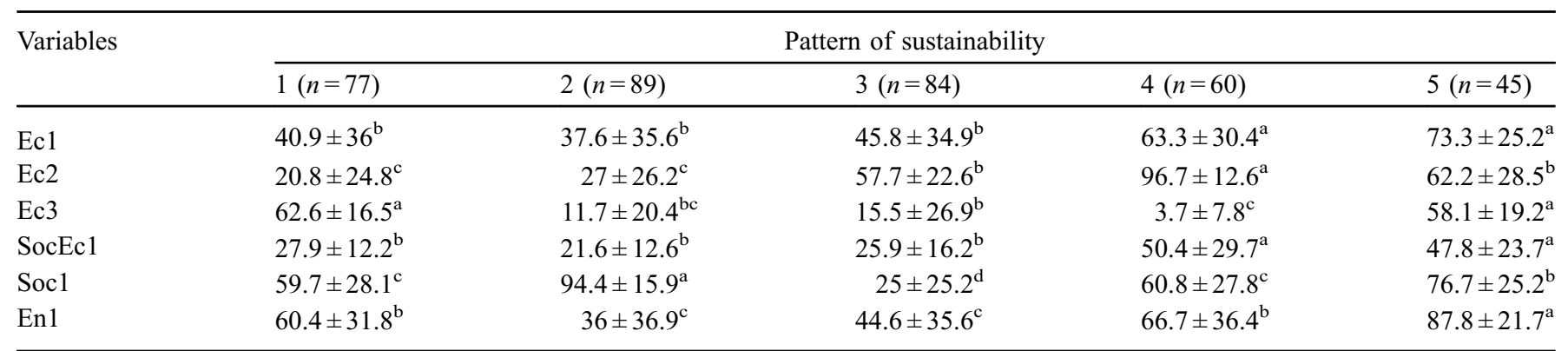

Means in the same column with a different superscript differ significantly $(P<0.05)$; NS not significant.

Source: Survey (2015).

is coherent with the literature on livestock farms in many countries of the world (Lebacq et al., 2015).

\subsection{Farm pluriactivity}

Pluriactivity also plays an important role in sustainability. It might support farmers' adaptability and reduce risks related to dairy business that are due to uncertainty of milk and input prices. Pluriactivity also promotes synergies between crop and livestock activities, such as organic fertilizing, use of crop residues for feed, or balancing labor along the year. Our survey shows that farmers used paddy straw from their crop land to reduce the cost of feed and that they used manure from dairy farm as organic fertilizer. More diversified farming systems also enable farmers to get higher income by using available time and family labor. Diversified activities are a way for farmers to use their resource (including family labor) optimally (Ryschawy et al., 2013). Our results suggest the potential ability of small-scale mixed crop-livestock farms to switch from one activity to another in case of a crisis or problem on one specific market. Some more research on farm trajectories would be needed to confirm this hypothesis. Our approach also underlines the fact that total farm income must be considered in the assessment of economic sustainability rather than partial dairy margin (García-Martínez et al., 2011). 
P. Sembada et al.: Cah. Agric. 2019, 28, 15

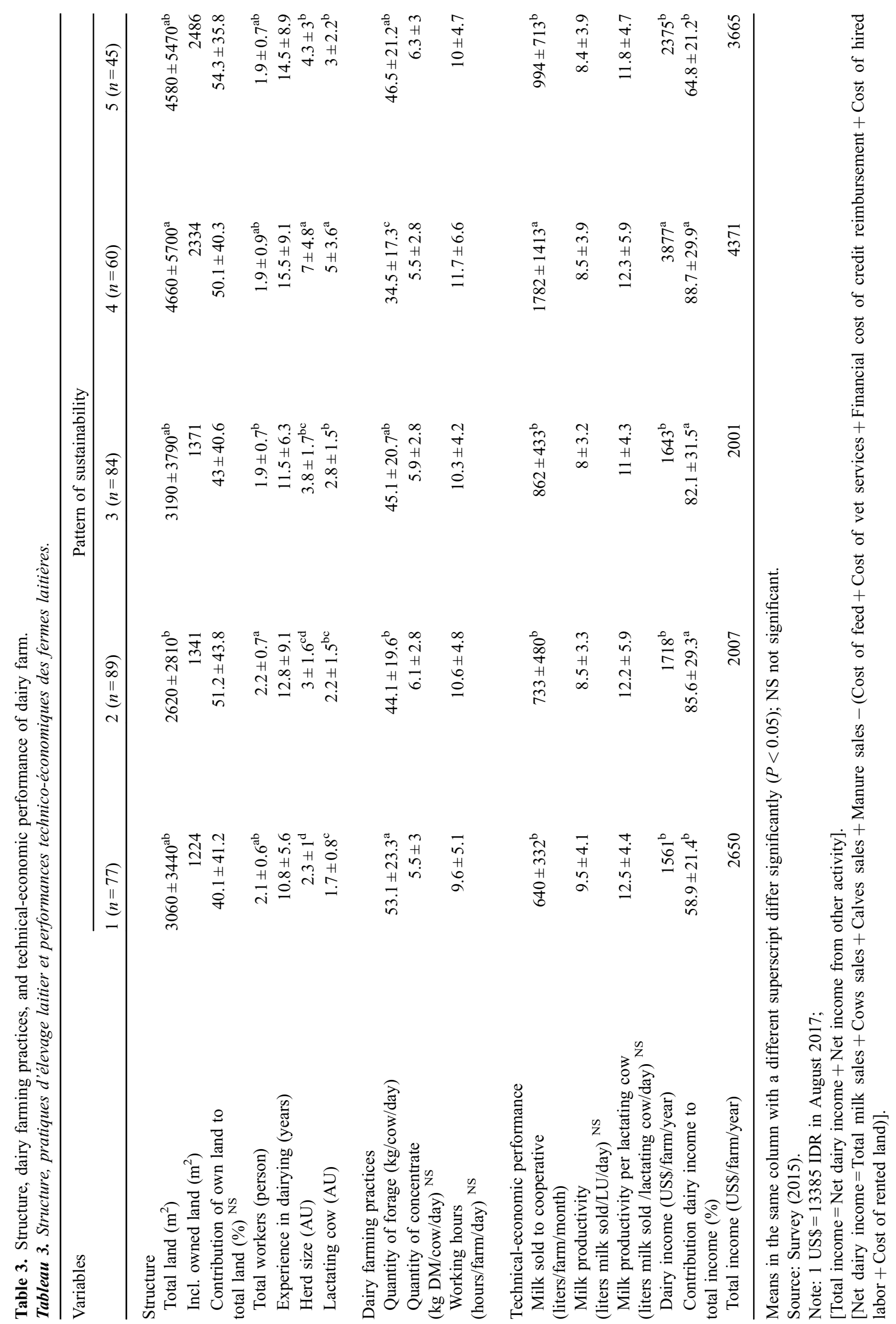




\subsection{First assessment of social dimension of sustainability}

With regard to the social dimension of sustainability, the result showed that an important proportion of farmers expected their children to find other activities than farming. Due to their small size of herd and land, dairy income generate less than the local average minimum wage. This illustrates the fact that economic dimension of sustainability is strongly linked with social dimension (Lebacq et al., 2013).

\subsection{Waste management}

In terms of environmental performances, our study focused on waste management. For this question, we showed that small intensive farms can easily manage waste efficiently, if good practices and appropriate equipment are promoted such as organic fertilizing and biogas systems. The majority of surveyed farmers received biogas equipment and installation from dairy development project by cooperative, $\mathrm{NGO}$, government and others. They obtained it for free, and some others by credit scheme through dairy cooperative. In other words, every farmers could access it. Some farmers did not install biogas equipment due to limited space (small size of owned land) at barn.

\section{Conclusion}

The smallholder dairy development has been widespread in the country. In Indonesia as a whole, between 1985 and 2012 , milk production was multiplied by 5 . This rapid dairy development has relied mostly on smallholder farms, thereby providing high economic and social impacts on rural communities. However, since 2011, the growth of the dairy sector has stopped. Between 2012 and 2015, the domestic milk production decreased. As a result, the share of the milk powder imports in the total consumption has grown. The competition from imported powder milk appears to be a major constraint to the development of local farms. In addition, Indonesian farmers are facing many technical and organizational constraints. In that context, new types of partnership between farmers, cooperatives, government services and private processors are expected to foster the collection of local milk. The objective of such partnerships is to promote sustainable and inclusive dairy value chain.

In the future, policies and projects related to credit provision, land re-distribution, and farmers' economic and technical trainings will be needed to secure the livelihoods of those farmers. If farms with higher capital will be expected to be more sustainable, due to the fact that they will reach higher technico-economic performance and overall sustainability, it will not be the case for the majority of very small farms that will need to be supported by cooperatives and public institutions. Those policies will have to consider specialized dairy farms as well as diversified dairy farms, since those diversified farmers might be less vulnerable and more adaptable on the long run. Our findings underline that policy programs that support farmers in increasing their capital, and in diversifying their farming activities can boost the sustainability of the whole national dairy system. The study also suggests that if farmers' income does not rise sufficiently, most of farmers' children will prefer to find jobs in other sectors that in dairy production. If the role of public authorities has to be underlined, the support of the sustainable development of smallholder dairy farms is also heavily determined by the strategies of private dairy industries.

Acknowledgment. The authors gratefully acknowledge the Danone Ecosystem Fund who supported this study, together with the Center for International Cooperation in Agricultural Research for Development (CIRAD, France). We are also thankful to Sahabat Cipta Foundation, the KPSBU cooperative, local communities and producers for their cooperation during the field survey. A former version of this paper was presented at SFER conference in Lyon, December 2017.

\section{References}

Badan Pusat Statistik (BPS). 2013. Sensus Pertanian 2013, Jakarta. [BPS-Statistics Indonesia. 2013. Agricultural Census 2013, Jakarta].

Devendra C. 2001. Smallholder dairy production systems in East and South-East Asia: Expanding importance, environmental impacts and opportunities for improvements. Smallhold. Dairy Prod. Mark. Constraints 141-159.

García-Martínez A, Bernués A, Olaizola AM. 2011. Simulation of mountain cattle farming system changes under diverse agricultural policies and off-farm labour scenarios. Livest. Sci. 137: 73-86. DOI: https://doi.org/10.1016/j.livsci.2010.10.002.

Herrero M, Thornton PK, Gerber P, Reid RS. 2009. Livestock, livelihoods and the environment: Understanding the trade-offs. Curr. Opin. Environ. Sustain. 1: 111-120. DOI: https://doi.org/ 10.1016/j.cosust.2009.10.003.

Lebacq T, Baret PV, Stilmant D. 2013. Sustainability indicators for livestock farming. A review. Agron. Sustain. Dev. 33: 311-327. DOI: https://doi.org/10.1007/s13593-012-0121-x.

Lebacq T, Baret PV, Stilmant D. 2015. Role of input self-sufficiency in the economic and environmental sustainability of specialised dairy farms. Animal 9: 544-552. DOI: https://doi.org/10.1017/ S1751731114002845.

López-Ridaura S, Masera O, Astier M. 2002. Evaluating the sustainability of complex socio-environmental systems. The MESMIS framework. Ecol. Indic. 2: 135-148.

Moran J. 2009. Business management for tropical dairy farmers. Collingwood, Victoria, Australia: Landlinks Press.

Ryschawy J, Choisis N, Choisis JP, Gibon A. 2013. Paths to last in mixed crop-livestock farming: Lessons from an assessment of farm trajectories of change. Animal 7: 673-681. DOI: https://doi.org/ 10.1017/S1751731112002091.

Sembada P, Duteurtre G, Purwanto BP, Suryahadi S. 2016. Improved milk production performance of smallholder farms in West Java (Indonesia). Trop. Anim. Health Prod. DOI: https://doi.org/ 10.1007/s11250-016-1029-2.

Cite this article as: Sembada P, Duteurtre G, Moulin C-H. 2019. The essential role of farm capital in the sustainability of smallholder farms in West Java (Indonesia). Cah. Agric. 28: 15. 